\title{
Shifted migration of the rape stem weevil Ceutorhynchus napi (Coleoptera: Curculionidae) linked to climate change
}

\author{
Michael EICKERMANN ${ }^{1}$, MARco BEYER ${ }^{1}$, Klaus GOERGEN $^{1,2}$, LUCIEN HOFFMANN ${ }^{1}$ and JÜRGEN JUNK ${ }^{1}$
}

${ }^{1}$ Centre de Recherche Public - Gabriel Lippmann, Département Environnement et Agro-biotechnologies (EVA), 41, rue du Brill, L-4422 Belvaux, Luxembourg; e-mails: eickerma@lippmann.lu; beyer@lippmann.lu; hoffmann@lippmann.lu; junk@lippmann.lu

${ }^{2}$ Meteorologisches Institut der Universität Bonn, Rheinische Friedrich-Wilhelms-Universität Bonn, Meckenheimer Allee 176, D-53115 Bonn, Germany; e-mail: goergen@uni-bonn.de

Key words. Coleoptera, Curculionidae, Ceutorhynchus napi, crop invasion, ensemble projection, impact study, regional climate model

\begin{abstract}
A multi-model ensemble of 15 climate change projections from regional climate models was used to assess the impact of changes in air temperature and precipitation on the phenology of pest species in agriculture. This allowed the bandwidths of expected changes in both meteorological variables to be calculated, forming the basis for assessing and clearly communicating the uncertainties related to the model results. More specifically, we investigated the potential impact of regional climate change effects on the crop invasion of the rape stem weevil, Ceutorhynchus napi Gyllenhal (Coleoptera: Curculionidae), in Central Europe (Luxembourg). Multisite and perennial data from field observations were used to choose a biological model from the literature, based on daily maximum air temperature and daily totals of precipitation to describe the migration of C. napi. Based on this statistical relation, we were able to reproduce the observed crop invasion with a mean root mean squared error (RMSE) of 10 days. Daily values of projected maximum air temperatures and daily totals of precipitation of the multi-model ensemble were used as input data for the threshold-based biological model that projects the immigration of this pest species into oilseed rape crops (Brassica napus L.). We examined three thirty-year timespans, the near (2021 to 2050) and the far future (2069 to 2098) and compared them to a reference timespan (1961 to 1990). The projections showed a significant shift of crop invasion to an earlier onset for the near (14 days) and far future (21 days) compared to the reference period. In addition, the timespan in which the potential crop invasion will take place increased from 53 days in the reference timespan to 73 days in the near and 65 days in the far future based on the ensemble median values. It could be expected that a shifting of the immigration period will increase the risk of missing the appropriate time frame for an insecticide application. A depletion of stored nutrient resources, leading to starvation after diapause, can be eliminated for C. napi under climate change effects, as this species hibernates motionless as an adult in earth cocoons until emergence in early springtime driven by temperature.
\end{abstract}

\section{INTRODUCTION}

Effects of global change on applied plant protection were recently reviewed (Juroszek \& Tiedemann, 2013), and possible impacts of increasing air temperature are expected, especially for pest species (Kocmánková et al., 2011) in agricultural crop production. So far, the effects of climate change on herbivore phenology in oilseed rape (Brassica napus L.) have been described for the cabbage seedpod weevil, Ceutorhynchus obstrictus (Marsham) (Olfert \& Weiss, 2006), and the cabbage stem weevil, Ceutorhynchus pallidactylus (Mrsh.) (Junk et al., 2012).

However, the effects of a future changing climate on the rape stem weevil, Ceutorhynchus napi Gyllenhal (Col.: Curculionidae), a common pest in oilseed rape causing significant yield losses (Williams, 2010), have not yet been investigated. $C$. napi is a univoltine species with three larval instars (Günthart, 1949). Adults immigrate to oilseed rape crops from their overwintering habitats in the soil of previous year's crop in early springtime (Alford et al., 2003). After a short feeding time for ovary maturation, C. napi females oviposite individual eggs into the top of the main stems or lateral racemes close to the growing tip of the plants (Williams, 2010). The larvae mine within the pith of host plants. Mature larvae migrate into the soil for pupa- tion. Adult stage is reached after 5 weeks, but the adults do not emerge from the cocoons until following spring (A1ford et al., 2003). C. napi is present in Central Europe (Alford et al., 2003) and hence also common in Luxembourg (Braunert, 2009). In recent years, forecast systems for the crop invasion of $C$. napi were developed to advise farmers on the timing of insecticide applications (Johnen et al., 2010). Most of these forecast systems are based on simple threshold models using variables like soil and air temperature (Fritzsche, 1956).

Luxembourg was chosen as a test area because extensive field observations of the rape stem weevil were available for the validation of the results of the statistical models describing the migration behavior of $C$. napi. The methodology presented here can be easily transferred to other regions by adjusting the meteorological threshold values.

The results from a dynamical downscaling of numerical climate model projections are an essential part of regional climate change assessments and impact studies. Global (GCM) and regional climate models (RCM) are well established tools to simulate the potential future climate but still afflicted by different uncertainties e.g. due to the initial or boundary conditions, the emission scenarios, or by the fact that some physical processes are not fully implemented 
(Knutti et al., 2010). One way to deal with these uncertainties is to analyze an ensemble of equally valid, possible realizations of regional climate change projections.

We used a multi-model ensemble to derive bandwidths of possible changes and thereby also assess the uncertainty associated with the projected changes. This is currently considered good-practice in impact studies (Knutti et al., 2010). In contrast to other studies, e.g. Carvalho et al. (2010), we used a single biological impact model, but an ensemble of climate change projections based on the same greenhouse gas emission scenario, A1B (Solomon et al., 2007). Thus, it is possible to adequately capture the range of uncertainties associated with climate projections (Beaumont et al., 2007) and to understand the range of effects that are expected in the future (Kocmánková et al., 2011).

The main objective of the present study was to evaluate the migration of $C$. napi to oilseed rape crops under the effects of regional climate change conditions based on a multi-model approach in order to show the uncertainties related to the climate change projections.

\section{MATERIAL AND METHODS}

\section{In situ meteorological observations}

For the description of the average climatological conditions in Luxembourg we used observations of daily maximum air temperature and daily precipitation totals from the SYNOP (surface synoptic observations) station at Luxembourg-Findel Airport (WMO station ID $=065900$ ). This station, the only official SYNOP station in Luxembourg, is located in the south-east of the City of Luxembourg $\left(49^{\circ} 37^{\prime} \mathrm{N}, 06^{\circ} 13^{\prime} \mathrm{E}, 379 \mathrm{~m}\right.$ a.s.1.).

Furthermore, daily values of maximum air temperature (measured at $2 \mathrm{~m}$ height) and total precipitation (measured at $1 \mathrm{~m}$ height) were taken from the meteorological monitoring network stations of the "Administration des Services Techniques de l'Agriculture" (ASTA), as well as from our own standard automatic weather station (AWS) (Fig. 1) for the period from 2007 until 2011. Unfortunately, for these stations no long-term data sets are available; therefore Findel was used as climatological reference.

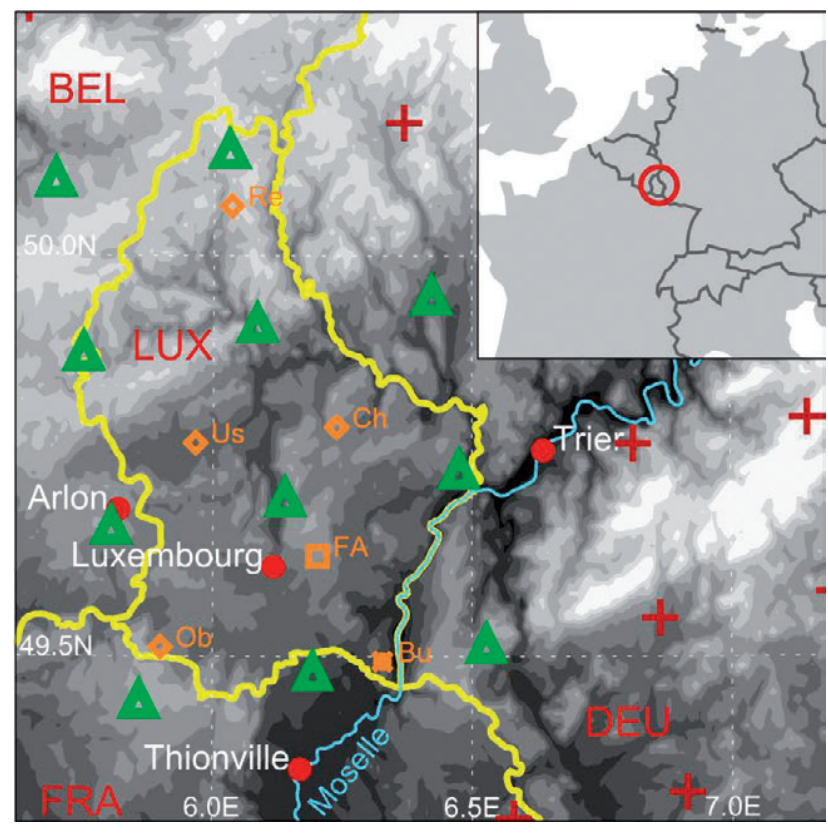

Fig. 1. Geographical overview of the study area and the field sites. Orange diamonds (ASTA) and crosses (own network): biological observation sites and meteorological stations used; $\mathrm{Bu}-$ Burmerange, $\mathrm{Ob}$ - Obercorn, $\mathrm{Ch}$ - Christnach, Us - Useldange, $\mathrm{Re}$ - Reuler; orange rectangle: Findel Airport station. Red/green crosses/triangles: spatial distribution of $25 \mathrm{~km}$ resolution RCM grid points, grid elements used to derive the time-series for Luxembourg are highlighted as triangles in green; selected are grid points that have any overlap with Luxembourg. Yellow: national borders. Inset: Luxembourg's location within Europe. Topographie USGS GTOPO30.

\section{Regional climate change projections}

Fifteen out of 22 available regional climate change model results from the Research Theme 2B of the EU-FP6 ENSEMBLES project (van der Linden \& Mitchell, 2009) were used (Table 1). Seven models were omitted because they only partly covered the whole timespan from 1961 to 2098.

TABLE 1. List of regional climate change model results used in this study; emission scenario: A1B, spatial resolution: $25 \mathrm{~km} \times 25 \mathrm{~km}$, temporal resolution: daily data; timespan: 1961-2098. For more detail see van der Linden \& Mitchell (2009).

\begin{tabular}{lcccc}
\hline $\begin{array}{l}\text { Driving Global Climate Model } \\
\text { (GCM) }\end{array}$ & $\begin{array}{c}\text { Model } \\
\text { abbreviation }\end{array}$ & Institution & $\begin{array}{c}\text { Regional Climate Model (RCM) } \\
\text { used for downscaling }\end{array}$ & Institution \\
\hline HadCM3Q16 & M1 & METO-HC & RCA3 & C4I \\
ARPEGE_RM5.1 & M2 & CNRM & ALADIN & CNRM \\
ECHAM5r3 & M3 & MPI-MET & DMI-HIRHAM5 & DMI \\
ARPEGE & M4 & CNRM & HIRHAM5 & DMI \\
BCM & M5 & UIB & HIRHAM5 & DMI \\
HadCM3Q0 & M6 & METO-HC & CLM & ETHZ \\
HadCM3Q0 & M7 & METO-HC & HadRM3Q0 & METO-HC \\
HadCM3Q3 & M8 & METO-HC & HadRM3Q3 & METO-HC \\
HadCM3Q16 & M9 & METO-HC & HadRM3Q16 & METO-HC \\
ECHAM5r3 & M10 & MPI-MET & RegCM & ICTP \\
ECHAM5r3 & M11 & MPI-MET & RACMO & KNMI \\
ECHAM5r3 & M12 & MPI-MET & REMO & MPI-M \\
BCM & M13 & UIB & RCA3 & SMHI \\
ECHAM5r3 & M14 & MPI-MET & RCA3 & SMHI \\
HadCM3Q3 & M15 & METO-HC & SMHI \\
\hline
\end{tabular}


TABLE 2. Thirty-year (1961-1990) long-term monthly mean air temperatures (long-term annual mean $=8.3^{\circ} \mathrm{C}$ ) and precipitation (long-term annual amount $=874 \mathrm{~mm}$ ) at the Findel SYNOP station in Luxembourg $(\mathrm{STD}=$ standard deviation).

\begin{tabular}{|c|c|c|c|c|c|c|c|c|c|c|c|c|}
\hline & Jan. & Feb. & Mar. & Apr. & May & Jun. & Jul. & Aug. & Sep. & Oct. & Nov. & Dec. \\
\hline \multicolumn{13}{|c|}{ Temperature $\left({ }^{\circ} \mathrm{C}\right)$} \\
\hline Mean & 0.0 & 1.1 & 4.0 & 7.5 & 11.8 & 14.9 & 16.9 & 16.4 & 13.4 & 9.1 & 3.9 & 1.0 \\
\hline STD & 2.6 & 2.6 & 1.9 & 1.4 & 1.6 & 1.4 & 1.8 & 1.3 & 1.4 & 1.5 & 1.4 & 1.9 \\
\hline \multicolumn{13}{|c|}{ Precipitation $\left(\mathrm{mm} \mathrm{month}{ }^{-1}\right)$} \\
\hline Mean & 71 & 62 & 70 & 61 & 81 & 82 & 68 & 72 & 70 & 74 & 83 & 80 \\
\hline STD & 38 & 40 & 35 & 37 & 41 & 45 & 33 & 29 & 36 & 51 & 31 & 47 \\
\hline
\end{tabular}

All projections were based on the Special Report on Emissions (SRES) A1B emission scenario of the Intergovernmental Panel on Climate Change, IPCC (Solomon et al., 2007). This scenario describes anthropogenic emissions in a future world with rapid economic growth, an increasing global population until the middle of this century and a balanced use of fossil and non-fossil energy resources. It is widely used in impact assessments due to data availability (Shindell et al., 2007; Weilin et al., 2011) and it is the only emission scenario used in the ENSEMBLE project (van der Linden \& Mitchell, 2009).

The period from 1961 to the year 2000 is considered as the control period based on observed twentieth century emissions, and is followed by the projection period from 2001 to 2100 in which the IPCC A1B emission scenario was used (Solomon et al., 2007). As the HadCM3-driven RCM (Table 1) temporal coverage ends in November 2099, the far-future timespan is defined from 2069 to 2098, the near-future from 2021 to 2050. The thirty years from 1961 to 1990 define the reference period according to the official valid reference period defined by the World Meteorological Organization. The variables used for our analyses are the daily maximum air temperature and daily total precipitation. To derive spatial means for Luxembourg from the ENSEMBLE data, all grid cells that overlap with Luxembourg's spatial domain are averaged using a weighing factor per grid element based on the respective overlap area.

Hence, a threshold-driven approach was used to describe the migration of $C$. napi to oilseed rape crops, for which absolute values of the meteorological variables were necessary. Therefore, a bias correction of the model output was required (Piani et al., 2010). A non-linear bias correction method using the E-OBS data (Haylock et al., 2008) set was used to correct the daily model output. A detailed description of the approach is given by Nilson et al. (2010). The necessary correction factors are determined for the reference timespan from 1961 to 1990 and afterwards applied to the complete time-series from 1961 to 2100 . According to Rojas et al. (2011), we also assumed a stationary error model for the future time frames. Following Christensen et al. (2010) and Ylhäisi et al. (2010), model weighting adds an additional level of uncertainty to the ensemble based climate projections. Therefore, no weighting factors were applied to individual RCM results in our study.

\section{Biological models}

Different biological models from the literature (Dosse, 1951; Fritzsche, 1956; Debouzie \& Wimmer, 1992) - all based on meteorological variables e.g. air temperature and precipitation - were tested based on our field observations of crop invasion of $C$. napi. The biological model by Debouzie \& Wimmer (1992) is one of the most common, freely available tools to predict the migration of the rape stem weevil and takes the daily maximum air temperature, as well as daily totals of precipitation, into account. These variables were measured at all our test sites in Luxembourg. The model showed the best agreement with field observations and was therefore combined with the results of the ENSEMBLES project to analyze the possible effects of changing air temperatures and precipitation amounts. The model was used to predict the day of the year (DOY) of crop invasions by $C$. napi based on the follow-

TABLE 3. Annual values of mean maximum air temperature and precipitation of the five meteorological stations near the experimental sites (less than $2 \mathrm{~km}$ ).

\begin{tabular}{lcrrrrrr}
\hline & & 2007 & 2008 & 2009 & 2010 & 2011 & 2012 \\
\hline Air temperature $\left({ }^{\circ} \mathrm{C}\right)$ & & & & & & & \\
\hline \multirow{2}{*}{ Burmerange } & Mean & 14.0 & 13.2 & 13.6 & 12.6 & 15.5 & 10.1 \\
& STD & 7.4 & 7.6 & 8.3 & 9.4 & 7.8 & 6.9 \\
Obercorn & Mean & 12.1 & 11.4 & 11.6 & 10.4 & 11.7 & 9.8 \\
& STD & 6.5 & 6.8 & 7.5 & 8.3 & 6.7 & 7.2 \\
Useldange & Mean & 11.4 & 10.6 & 10.8 & 9.7 & 11.2 & 10.1 \\
& STD & 6.4 & 6.8 & 7.4 & 7.9 & 6.4 & 6.9 \\
Christnach & Mean & no value & 10.6 & 10.1 & 9.0 & 11.1 & 10.2 \\
& STD & & 6.7 & 7.4 & 8.0 & 6.5 & 7.1 \\
Reuler & Mean & 9.7 & 9.9 & 9.3 & 7.8 & 10.2 & 8.4 \\
\hline Precipitation $(\mathrm{mm})$ & STD & 6.2 & 6.6 & 7.5 & 8.5 & 6.4 & 6.9 \\
\hline Burmerange & & & & & & & \\
Obercorn & Sum & 798 & 655 & 628 & 496 & 530 & 709 \\
Useldange & Sum & 1135 & 1000 & 971 & 934 & 771 & 979 \\
Christnach & Sum & 834 & 974 & 825 & 667 & 505 & 859 \\
Reuler & Sum & & 702 & 751 & 621 & 531 & 831 \\
\hline
\end{tabular}




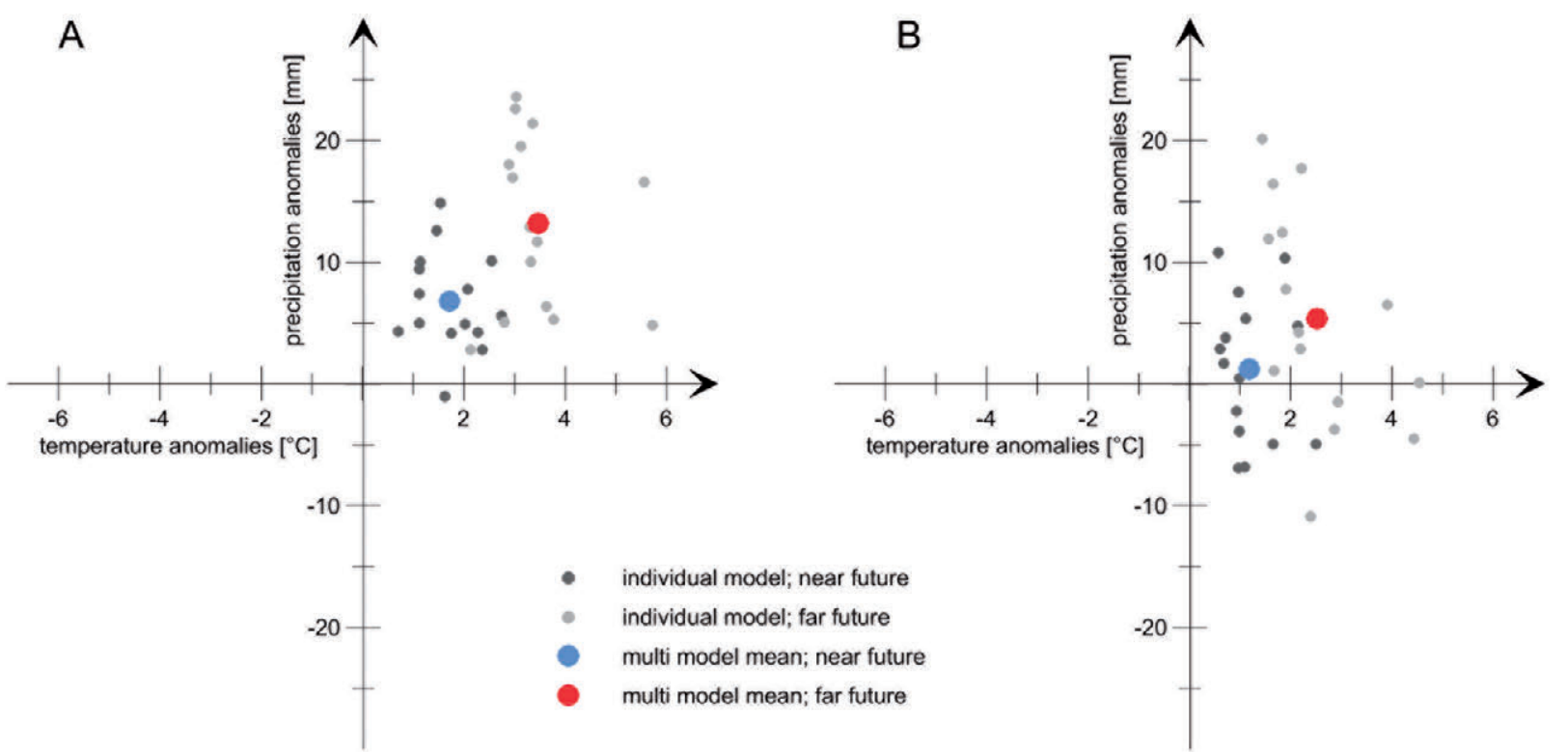

Fig. 2. Anomalies of air temperature and precipitation for the meteorological seasons winter (A) and spring (B) for two different future timespans (near future $=2021$ until 2050 and far future $=2069$ until 2098) with respect to the reference period from 1961 till 1990. Long-term annual mean air temperature in winter $=0.7^{\circ} \mathrm{C}$, spring $=7.4^{\circ} \mathrm{C}$; long-term annual mean precipitation in winter $=200$ $\mathrm{mm}$, spring $=135 \mathrm{~mm}$. Given are individual values of each model (small dots), which represent the mean values of a thirty-year period, as well as the multi model median of all models (bigger dots).

ing conditions: (i) before 15 March, a maximum air temperature $>9^{\circ} \mathrm{C}$ on 3 consecutive days, (ii) no precipitation is observed on those days and (iii) after 15 March, a single day with a maximum air temperature $>9^{\circ} \mathrm{C}$ and no precipitation are sufficient to initiate migration (Debouzie \& Wimmer, 1992).

\section{In situ biological observations}

Field data collected in a perennial (2007 to 2012), multilocated monitoring programme was used for comparison with the predicted crop invasion of $C$. napi according to the phenological model by Debouzie \& Wimmer (1992). Individuals of $C$. napi were caught at five locations in Luxembourg: Burmerange (49 $29^{\prime} \mathrm{N}, 6^{\circ} 19^{\prime} \mathrm{E}, 222 \mathrm{~m}$ a.s.1.), Obercorn (493 $31^{\prime} \mathrm{N}, 5^{\circ} 51^{\prime} \mathrm{E}, 313$ $\mathrm{m}$ a.s.1.), Useldange $\left(49^{\circ} 46^{\prime} \mathrm{N}, 5^{\circ} 57^{\prime} \mathrm{E}, 307 \mathrm{~m}\right.$ a.s.1.), Christnach $\left(49^{\circ} 47^{\prime} \mathrm{N}, 06^{\circ} 16^{\prime} \mathrm{E}, 313 \mathrm{~m}\right.$ a.s.1.) and Reuler $\left(50^{\circ} 03^{\prime} \mathrm{N}, 06^{\circ} 02^{\prime} \mathrm{E}\right.$, $472 \mathrm{~m}$ a.s.1.) For monitoring yellow water traps $(30 \mathrm{~cm} \times 30 \mathrm{~cm} \times$ $15 \mathrm{~cm}, 8$ traps per location) were installed along the field borders in areas where no insecticide was applied during the growing season. The trap height was adjustable from ground level to $1.7 \mathrm{~m}$ above ground. Three small holes ( $3 \mathrm{~mm}$ in diameter) were drilled into the middle of the side panels to assure a relatively constant water level in the trap ( 31 per trap) by avoiding the accumulation of rainwater. The traps were controlled and insects were sampled twice per week (Monday and Thursday). A small quantity of soap was added to the water in the traps to break the surface tension thereby drowning the insects (Williams, 2010). The captured insects were stored in plastic containers in a $70 \%$ ethanol solution, before being manually identified and counted by using binoculars. Individuals of $C$. napi were separated from other pest insects and determined using an identification key (Alford et al., 2003).

\section{Statistics}

We used the Kolmogoroff-Smirnoff test to check whether the projected frequency distributions of crop invasion (Fig. 5) showed a Gaussian distribution. Since this was not the case for all 15 models, the non-parametric Mann-Whitney rank sum test (SigmaStat Ver. 3.0, Erkrath, Germany) was used to test whether there were statistically significant differences between the fre- quency distributions of the migration periods between the reference period (1961 to 1990) and the two future timespans (2021 to $2050 ; 2069$ to 2098).

\section{RESULTS}

\section{In situ climatological conditions}

The annual mean air temperature for Luxembourg (Findel Airport station) was $8.3^{\circ} \mathrm{C}$ (1961 to 1990$)$. The climate is semi-oceanic with mild winters and moderate summers. The warmest month is July with a long-term mean air temperature of $16.9^{\circ} \mathrm{C}$ (Table 2). The precipitation amounts are almost equally distributed throughout the year and reach a long-term annual mean of $874 \mathrm{~mm}$.

In addition, Table 3 shows the annual values of mean maximum air temperature as well as precipitation sums for the five meteorological stations used in this study. All stations were in close vicinity to the test fields (less than 2 $\mathrm{km})$. Highest air temperature was reported for the station near Burmerange, while the highest precipitation amounts were observed in Reuler, situated in the north of Luxembourg.

\section{Projected climatological conditions}

Due to the fact that for the migration of C. napi the temperature and precipitation conditions in winter and spring were relevant, only these seasons were analyzed (Fig. 2a and b). Fourteen of the fifteen models showed a clear signal towards wetter winters (December, January and February) in the near future, while for the far future period, all models coincide (Fig. 2a). All models indicated higher air temperatures for both future timespans (Fig. 2a). In Fig. 2b, the same analysis is shown for the meteorological spring season (March, April and May). In contrast to the results for winter, the change signal of precipitation is 


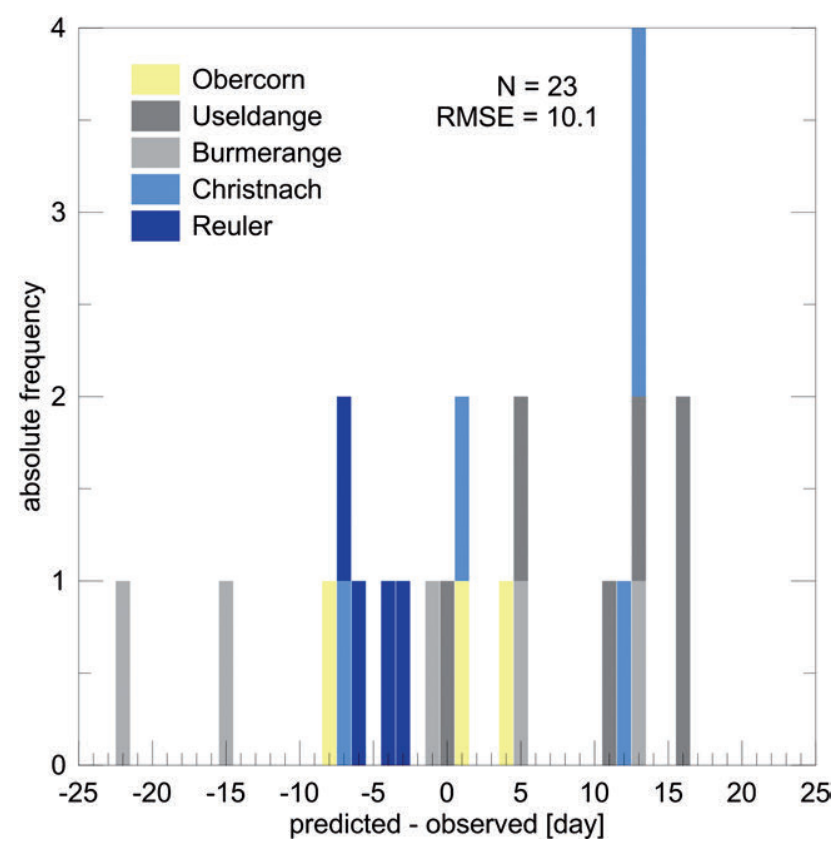

Fig. 3. Absolute frequencies of the differences in days between observed and predicted Day of Year (DOY) of the crop invasion (23 cases) by $C$. napi for the five observational sites for the period from 2007 to 2012. Different sites are indicated by different colours.

not so clear. Nevertheless, most of the models ( 9 out of 15 for the near and 4 out of 15 for the far future) predict wetter conditions, while all models indicate a trend towards higher air temperatures in the future.

\section{Selection and validation of the phenological model}

C. napi did not appear every year at every location. For example in Obercorn it was only observed in 2010 and 2011 because of a broad crop rotation within the region. For our study, 23 cases (year $\times$ location) were available for the comparison with the results based on the statistical model. The difference between the simulated and observed median values was smaller than the error that could be attributed to the interval of observations. On average, crop invasion was simulated, using the meteorological data sets from the weather stations from 2007 until 2011, on DOY 76 (17 March), whereas crop invasion was observed at the five experimental sites in situ on DOY 74 (15 March). The absolute differences between the observed and predicted dates of the crop invasion are shown in Fig. 3. In general, the simple statistical relation between crop invasion and meteorological conditions leads to satisfactory results $[$ mean root mean squared error $(\mathrm{RMSE})=10.1$ days $]$. The absolute difference between the predicted and observed date of crop invasion was, in 13 cases, below an error of 10 days and only in one case more than 20 days.

\section{Projected crop invasion of $\boldsymbol{C}$. napi}

Fig. 4 shows the effects of climate change on the crop invasion of $C$. napi on a specific day of the year calculated from daily data (maximum air temperature and precipitation sums) for each year from 1960 to 2098 and for each of the 15 models. The pronounced interannual variability of the invasion can be attributed either to individual weather events or to the variable meteorological conditions in general. In addition, the median values of the crop invasion of all 15 ensemble members were calculated (multi-model mean). It shifted from DOY 77 (18 March, STD 15.8) in the reference timespan to DOY 63 (4 March, STD 21.5) in the near future and DOY 56 (25 February, STD 20.8) in the far future. These shifts between the reference timespan and the two future periods were tested by the non-parametric Mann-Whitney rank sum test as statistically significant $(\mathrm{P}=0.05)$.

In Fig. 5, the individual results of all 15 models for the three different 30-year' timespan are presented via boxplots. The boxplots show the median and interquartile range (IQR), defined via the 25 and 75 percentile. The whiskers are calculated by a factor of $1.5 \times$ IQR. In addition, outliers are shown as grey points.

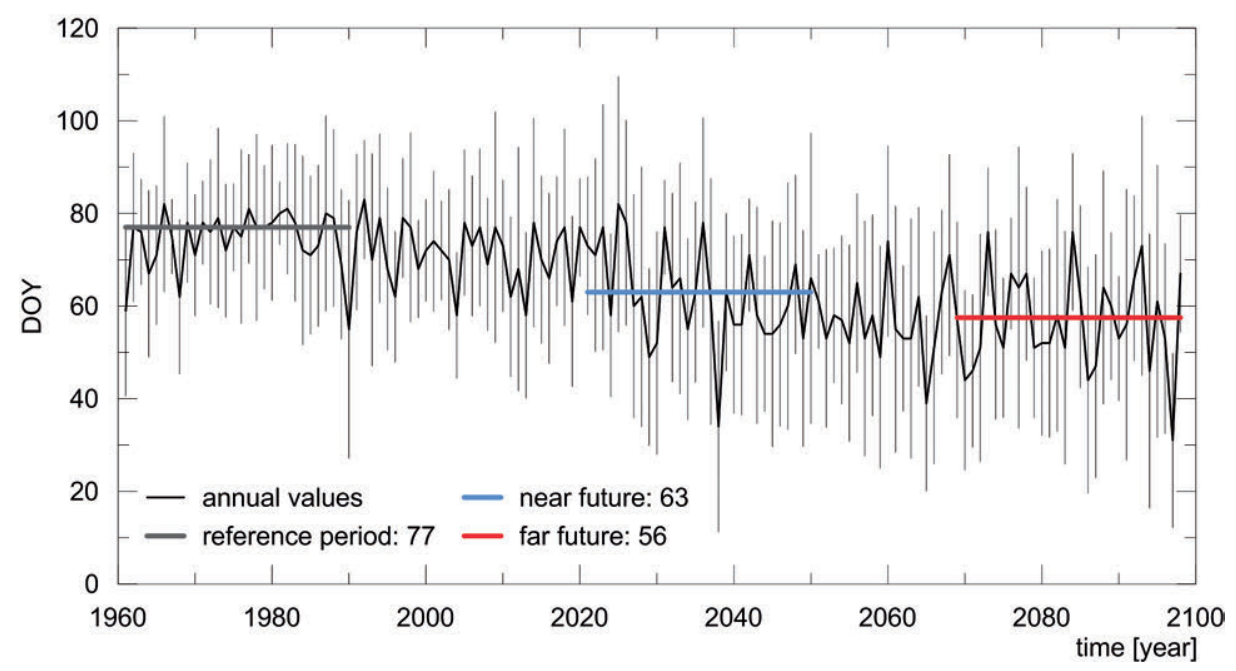

Fig. 4. Time series of the annual mean crop invasion of C. napi to crops of oilseed rape at Day of Year (DOY) (according to the model by Debouzie \& Wimmer, 1992): multi model $(\mathrm{n}=15)$ spread $( \pm 1 \times$ standard deviation, grey); multi model median (thin black line) with long-term annual means from 1961 until 1990 (reference period, DOY 77), 2021 until 2050 (near future, DOY 63 ), and 2069 until 2098 (far future, DOY 56). 

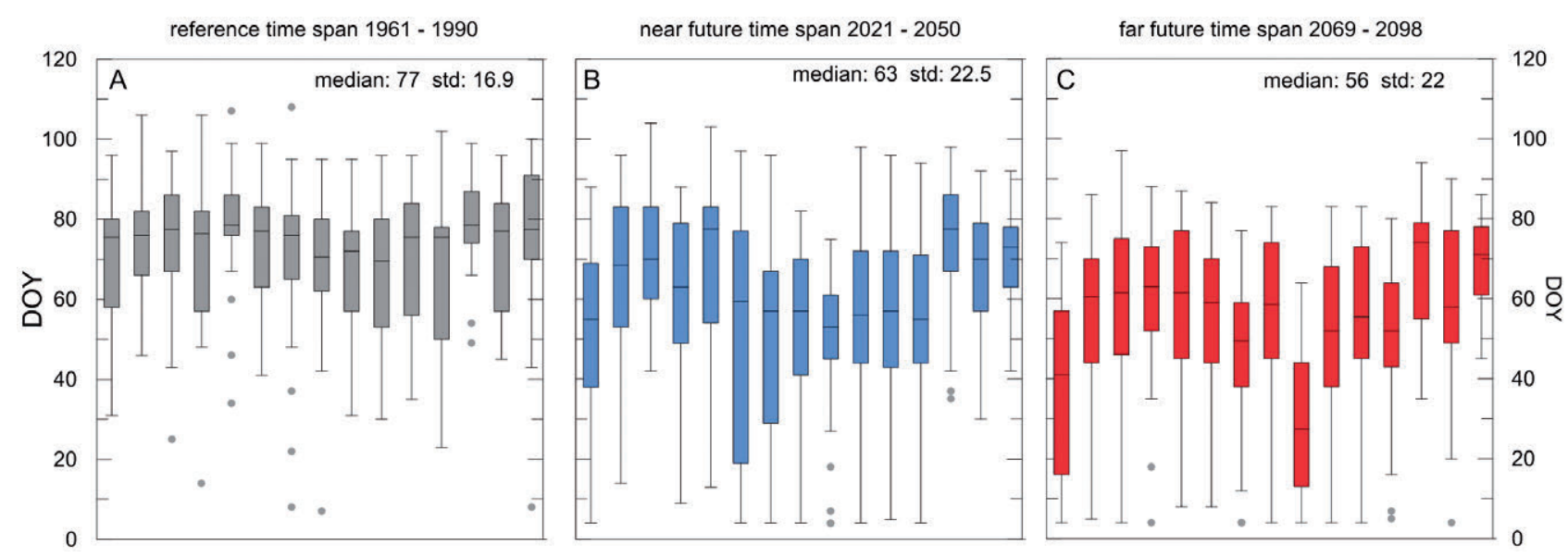

Fig. 5. Boxplots of individual model results $(\mathrm{N}=15)$ for the Day of Year (DOY) of the for the crop invasion by $C$. napi to crops of oilseed rape (according to the model of Debouzie \& Wimmer, 1992); for the reference time span (1961 until 1990 - A), the near future (2021 until $2150-$ B) and the far future (2069 until 2098 - C). The boxplots show the median and the interquartile range (IQR), defined via the 25 and 75 percentile. The whiskers are calculated by a factor of $1.5 \times$ IQR. In addition, outliers are shown as grey points.

Clear differences between the three timespans for the crop invasion of $C$. napi can be observed. In the reference timespan, the median of the appearance for the individual models varies between DOY 70 (11 March) and DOY 79 (20 March). In the near as well as the far future timespan the minimum median of all models decrease to DOY 53 and 28, respectively; while the maximum median of all models only slightly varies from 79 in the reference to 78 and 74 in the near and far future timespan.

The time span in which the potential crop invasion will take place based on the average minimum and maximum value of each of the models increased from 53 (STD 15.3) days in the reference period, to 73 (STD 15.9) in the near, and 65 (STD 15.6) in the far future. The elongation of this period is mainly caused by an earlier onset while the maximum values show only slight variations.

\section{DISCUSSION AND CONCLUSIONS}

The impact of global change on pest species in agriculture was previously discussed under aspects of species distribution (e.g. Sparks et al., 2007), life cycle (e.g. Kocmánková et al., 2011) or pest status of invasive species (e.g. Netherer \& Schopf, 2010). However, projections of increasing air temperature and related impacts to species phenology are still in early stages (Hodgson et al., 2011). For the first time, our study showed possible climate change effects on the migration of the rape stem weevil, $C$. napi, to oilseed crops in the future. In order to quantify the uncertainties related to climate change projections and the coupled impact model, a multi-model ensemble approach was used.

\section{Ensemble projections}

The advantages of using an ensemble of different regional climate projections have been shown in literature, recently (Juroszek \& von Tiedemann, 2013). Kocmánková et al. (2011) highlighted the usefulness of the multi-model ensemble approach which makes it possible to categorize the results from worst case to conservative scenarios. Recent coordinated efforts, such as the ENSEMBLES project, provided regionalized climate change projections, which form the basis for impact studies (Marletto et al., 2007). Instead of relying on the results of a single model, an ensemble of model results, either from different GCM-RCM combinations (as used in the present study) or the same GCM with slightly different initial conditions and/or physical settings can be used for climate projections. According to figure $5 \mathrm{~B}$, the use of a single model result, would lead to misinterpretations for the very early immigrations for C. napi.

On the contrary, one of the models misses late immigrations due to the underlying projected air temperatures. Combining all model projections, we were able to cover the whole bandwidth of expected change effects and thus, were able to assess the uncertainties of the future projections. Furthermore, the use of the multi-model ensemble of future climate projections leads to more accurate estimates of the potential future changes (Araújo \& New, 2007) because the effect of the internal variability could be more accurately addressed (May, 2008). On one hand, this makes the interpretation and communication of the results to nonscientific users (e.g. farmers or stakeholders) more complicated but, according to Knutti et al. (2010) and Cantelaube $\&$ Terres (2005), there is evidence that a multi-model average or median yields better prediction than a single model.

\section{Phenological models}

Phenological models of pest species are of major interest for decision support systems to determine the timing of insecticide applications (Johnen et al., 2010). The influence of different meteorological parameters on the emergence and immigration of $C$. napi to oilseed rape crops was described in the literature (Günthart, 1949; Dosse, 1951). The phenological model used for the present projections is based on two environmental factors: daily maximum air temperature and precipitation (Debouzie \& Wimmer, 1992). A comparison of the model output with the results obtained by field trapping showed a good agreement for the crop invasion of $C$. napi (RMSE: 10.1). The mean 
DOY for simulated crop invasion (17 March) was close to in situ data (15 March). The difference of two days may be explained by the fact that, crop invasion of the rape stem weevil is measured with yellow traps that are checked at a 3-day interval, only. However, some cases showed only a low correlation, e.g. at the site at Burmerange. At this station, higher wind speeds were observed throughout the year compared to the other locations. In addition at the site in Burmerange, the soil is loamier than at the other locations. This could prevent the immigration of $C$. napi to the fields after emergence from the soil (Dosse, 1951), because loamy soils are more humid, which can hamper the emergence.

\section{Projected crop invasion}

In our projections, a shift of about 21 days for the crop invasion of $C$. napi from the reference timespan (1961 to 1990 ) to the far future (2069 to 2098) was calculated. Similar effects have been shown for other pest species in oilseed rape, e.g. with an increasing air temperature of $3.0^{\circ} \mathrm{C}$ the diapause of $C$. obstrictus is expected to end two weeks earlier (Olfert \& Weiss, 2006).

As shown in the present study, the average climate conditions in Luxembourg in winter and springtime will change in the future. For the spring months, an average increase of the average maximum air temperature from $1.2^{\circ} \mathrm{C}$ (near future) up to $2.5^{\circ} \mathrm{C}$ (far future) is projected compared to the reference timespan. The obligate winter diapause is influenced by environmental parameters and can be shortened by increasing air temperature (Bale \& Hayward, 2010). A dry and warm springtime provides favourable conditions for the emergence of $C$. napi from the soil (Dosse, 1951) as well as for subsequent crop invasion (Debouzie \& Ballanger, 1993). However, an early crop invasion provides no information on the fitness of the individuals after the diapause (Bale \& Hayward, 2010). With respect to C. napi, an earlier activity in the overwintering habitat with combined energetic costs and a decreasing fitness can be eliminated under climate change conditions, because the rape stem weevil is hibernating motionless as an adult in earth cocoons until emerging in springtime (Alford et al., 2003).

In most European countries, C. napi invades oilseed rape crops together with another ceutorhynchid species, the cabbage stem weevil, C. pallidactylus (Williams, 2010). For oviposition, the cabbage stem weevil prefers host plants that have already been infested by the rape stem weevil (Dechert \& Ulber, 2004). Such a synchronized crop invasion is also an advantage for practical farming, as a single chemical application of insecticide is sufficient for controlling the pests. A shifting of activity to an earlier onset of 3 days per decade was projected for $C$. pallidactylus with an average air temperature increase of $3.1^{\circ} \mathrm{C}$ until 2098 (Junk et al., 2012). The synchronous appearance of both ceutorhynchid species in oilseed crops under future climate change effects should be tested in future studies.

With a shifting of the crop invasion, the risk of missing the appropriate time frame for an insecticide application is therefore higher (Harrington et al., 2001). For C. napi, an insecticide treatment needs to be carried out before females come to oviposition (Williams, 2010). In our projections, an increased timespan for the first immigration of $C$. napi was calculated for the near future timespan. The prolongation of approximately 17 days might be attributed to the higher variability of the air temperature values in the near future. Although the temperature increases, still relatively low temperatures could be observed in the meteorological spring. In the far future, this immigration period decreases again by 11 days. This could also be explained by the changes in the meteorological variable shown in Fig. 2a and $b$. The increasing air temperature values alone would (i) lead to an earlier onset of the immigration into the meteorological winter season and (ii) shorten the timespan for first immigration of C. napi overall. However, in parallel, the increasing precipitation values during the meteorological winter hinder the migration of the weevil to the crops due to less favourable migration conditions.

A prolonged period of flight activity or crop invasion is noticed under climate change conditions for other pest species in oilseed rape, e.g. C. pallidactylus (Junk et al., 2012) and several, univoltine butterfly species on brassicaceous host plants (Roy \& Sparks, 2000). In comparison to these studies, the influence of changing precipitation conditions was also taken into account in our projections. It is possible that more complex phenological models with a higher number of environmental factors, e.g. wind speed or soil properties can project possible impacts in more detail (Johnen et al., 2010). Farmers could benefit from the present results in various ways. On one hand, they would become aware that the period of crop invasion will start earlier, making an earlier monitoring activity of this pest species necessary. On the other hand, the timespan of possible crop invasion is prolonged, potentially making additional insecticide applications necessary.

ACKNOWLEDGEMENTS. We gratefully acknowledge the financial support of the Ministère de l'Enseignement supérieur et de la Recherche (MESR) of the Grand Duchy of Luxembourg in the framework of the REMOD programme. We are particularly grateful for valuable comments made by three anonymous reviewers on an earlier version of the manuscript. Additional thanks go to L. Stokes for language polishing.

\section{REFERENCES}

Alford D.V., Nilsson C. \& Ulber B. 2003: Insect pests of oilseed rape crops. In Alford D.V. (ed.): Biocontrol of Oilseed Rape Pests. Blackwell Science, Oxford, pp. 9-41.

AraúJo M.B. \& New M. 2007: Ensemble forecasting of species distributions. - Trends Ecol. Evol. 22: 42-47.

BaLe J.S. \& Hayward S.A.L. 2010: Insect overwintering in a changing climate. - J. Exp. Biol. 213: 980-994.

Beaumont L.J., Pitman A.J., Poulsen M. \& Hughes L. 2007: Where will species go? Incorporating new advances in climate modelling into projections of species distributions. - Glob. Change Biol. 13: 1368-1385.

BRAUNERT C. 2009: Verzeichnis der Rüsselkäfer Luxemburgs (Coleoptera, Curculionidae) mit Ausnahme der Borkenkäfer (Scolytinae) und Kernkäfer (Platypodinae). - Bull. Soc. Nat. Luxemb. 110: 125-142.

Cantelaube P. \& Terres J.-M. 2005: Seasonal weather forecasts for crop yield modelling in Europe. - Tellus (A) 57: 476-487. 
Carvalho S.B., Brito J.C., Crespo E.J. \& Possingham H.P. 2010: From climate change predictions to actions - conserving vulnerable animal groups in hotspots at a regional scale. - Glob. Change Biol. 16: 3257-3270.

Christensen J.H., KJellström E., Giorgi F., Lenderink G. \& RuMMUKAINEN M. 2010: Weight assignment in regional climate model. - Climate Res. 44: 179-194.

Debouzie D. \& Ballanger Y. 1993: Dynamics of a Ceutorhynchus napi population in winter rape fields. - Acta Oecol. 14: 603-618.

Debouzie D. \& Wimmer F. 1992: Models for winter rape crop invasion by the stem weevil Ceuthorhynchus napi Gyll. (Col., Curculionidae). - J. Appl. Entomol. 114: 298-304.

Dechert G. \& Ulber B. 2004: Interactions between the stemmining weevils Ceutorhynchus napi Gyll. and Ceutorhynchus pallidactylus (Mrsh.) (Coleoptera: Curculionidae) in oilseed rape. - Agr. Forest Entomol. 6: 193-198.

Dosse G. 1951: Der Große Kohltriebrüßler Ceutorrhynchus napi (Gyll.). - J. Appl. Entomol. 32: 489-566.

FriTZsCHE F. 1956: Untersuchungen zur Bekämpfung der Rapsschädlinge IV. Beiträge zur Ökologie und Bekämpfung des Grossen Rapsstengelrüsslers (Ceutorrhynchus napi Gyll.). Nachr. Bl. Dtsch. Pflanzenschutzd. 5: 97-105.

GÜNTHART E. 1949: Beiträge zur Lebensweise und Bekämpfung von Ceutorhynchus quadridens PANZ. und Ceutorhynchus napi Gyll. mit vielen Beobachtungen an weiteren Kohl- und Rapsschädlingen. - Mitt. Schweiz. Entomol. Ges. 23: 441591.

Harrington R., Fleming R.A., Woiwod I. 2001: Climate change impacts on insect management and conservation in temperate regions: can they be predicted? - Agr. Forest Entomol. 3: 233-240

Haylock M., Hofstra N., Klein A., Klok E., Jones P. \& New M. 2008: A European daily high-resolution gridded data set of surface temperature and precipitation for 1950-2006. - Geophys. Res. Lett. 113: D20119.

Hodgson J.A., Thomas C.D., Oliver T.H., Anderson B.J., BrERETON T.M. \& CRONE E.E. 2011: Predicting insect phenology across space and time. - Glob. Change Biol. 17: 1289-1300.

Johnen A., Williams I.H., Nielsson C., Klukowski Z., Luik A. \& Ulber B. 2010: The proPlant decision support system: Phenological models for the major pests of oilseed rape and their key parasitoids in Europe. In Williams I.H. (ed.): Biocontrol-Based Integrated Management of Oilseed Rape Pests. Springer, Dordrecht, pp. 381-403.

Junk J., Eickermann M., Görgen K., Beyer M. \& Hoffmann L. 2012: Ensemble-based analysis of regional climate change effects on cabbage stem weevil (Ceutorhynchus pallidactylus (Mrsh.)) in oilseed rape (Brassica napus L.). - J. Agric. Sci. 150: 191-202.

Juroszek P. \& von Tiedemann A. 2013: Plant pathogens, insect pests and weeds in a changing global climate: a review of approaches, challenges, research gaps, key studies and concepts. - J. Agric. Sci. 151: 163-188.

Knutti R., Furrer R., Tebaldi C., Cermak J. \& Meehl G.A. 2010: Challenges in combining projections from multiple climate models. - J. Climate 23: 2739-2758.

Kocmánková E., Trnka M., Eitzinger J., Dubrovský M., ŠtěPánek P., Semerádová D., Balek J., Skalák P., Farda A., JuROCH J. \& ŽALUD Z. 2011: Estimating the impact of climate change on the occurrence of selected pests at a high spatial resolution: a novel approach. - J. Agric. Sci. 149: 185-195.
Marletto V., Ventura F., Fontana G. \& Tomei F. 2007: Wheat growth simulation and yield prediction with seasonal forecasts and a numerical model. - Agr. Forest Meteorol. 147: 71-79.

MAY W. 2008: Potential future changes in the characteristics of daily precipitation in Europe simulated by the HIRHAM regional climate model. - Clim. Dynam. 30: 581-603.

Netherer S. \& Schopf A. 2010: Potential effects of climate change on insect herbivores in European forests - General aspects and the pine processionary moth as specific example. Forest Ecol. Manag. 259: 831-838.

Nilson E., Perrin C., Beersma J., Krahe P., Carambia M., De Keizer O. \& Görgen K. 2010: Evaluation of data and processing procedures. In Görgen K., Beersma J., Brahmer G., Buiteveld H., Carambia M., de Keizer O., Krahe P., Nilson E., Lammersen R., Perrin C. \& Volken D. (eds): Assessment of Climate Change Impacts on Discharge in the Rhine River Basin: Results of the RheinBlick2050 Project. International Commission for the Hydrology of the Rhine Basin (CHR), Lelystad, pp. $51-98$

Olfert O. \& Weiss R.M. 2006: Impact of climate change on potential distributions and relative abundances of Oulema melanopus, Meligethes viridescens and Ceutorhynchus obstrictus in Canada. - Agric. Ecosyst. Environ. 113: 295-301.

Piani C., Haerter J.O. \& Coppola E. 2010: Statistical bias correction for daily precipitation in regional climate models over Europe. - Theor. Appl. Climatol. 99: 187-192.

Rojas R., Feyen L., Dosio A. \& Bavera D. 2011: Improving panEuropean hydrological simulation of extreme events through statistical bias correction of RCM-driven climate simulation. - Hydrol. Earth Syst. Sci. 15: 2599-2620.

Roy D.B. \& Sparks T.H. 2000: Phenology of British butterflies and climate change. - Glob. Change Biol. 6: 407-416.

Shindell D.T., Faluvegi G., Bauer S.E., Koch D., Unger N., Menon S., Miller R.L., Schmidt G.A. \& Streets D.G. 2007: Climate response to projected changes in short-lived species under an A1B scenario from 2000-2050 in the GISS climate model. - J. Geophys. Res. 112: D20103.

Solomon S., Qin D., Manning M., Chen Z., Marquis M., Averyt K.B., Tignor M. \& Miller H.L. (eds) 2007: Climate Change 2007: The Physical Science Basis: Contribution of Working Group I to the Fourth Assessment Report of the Intergovernmental Panel on Climate Change. Cambridge University Press, Cambridge, 996 pp.

Sparks T.M., Dennis R.L.H., Croxton P.J. \& Cade M. 2007: Increased migration of Lepidoptera linked to climate change. Eur. J. Entomol. 104: 139-143.

VAN DER Linden P. \& Mitchell J.F.B. 2009: ENSEMBLES: Climate Change and it's Impacts: Summary of Research and Results from the ENSEMBLES Project. Met Office Hadley Centre, Exeter, $160 \mathrm{pp}$.

Weilin C., Zhinong J. \& Laurent L. 2011: Probabilistic projections of climate change over China under the SRES A1B scenario using 28 AOGCMs. - J. Climate 24: 4741-4756.

WiLLIAMS I.H. 2010: The major insect pests of oilseed rape in Europe and their management: an overview. In Williams I.H. (ed.): Biocontrol-Based Integrated Management of Oilseed Rape Pests. Springer, Dordrecht, pp. 1-43.

Ylhäisi J.S., Tietäväinen H., Peltonen-Saino P., Venäläinen A., EkLund J., RÄISÄNEN J. \& JYLHÄ K. 2010: Growing season precipitation in Finland under recent and projected climate. Nat. Hazard Earth Sys. 10: 1563-1574.

Received June 25, 2013; revised and accepted November 22, 2013 Prepublished online February 21, 2014 